慶應義塾大学学術情報リポジトリ

Keio Associated Repository of Academic resouces

\begin{tabular}{|c|c|}
\hline Title & $\begin{array}{l}\text { Different effects of norepinephrine and serotonin on the electrical toe stimulation-induced } \\
\text { reflexes in the rat spinal cord }\end{array}$ \\
\hline \multicolumn{2}{|l|}{ Sub Title } \\
\hline Author & $\begin{array}{l}\text { 鈴木, 岳之(Suzuki, Takeshi) } \\
\text { 小野, 秀樹(Ono, Hideki) } \\
\text { 福田, 英臣(Fukuda, Hideomi) }\end{array}$ \\
\hline Publisher & 共立薬科大学 \\
\hline Publication year & 1988 \\
\hline Jtitle & $\begin{array}{l}\text { 共立薬科大学研究年報 (The annual report of the Kyoritsu College of } \\
\text { Pharmacy). No.33 (1988. ) ,p.157-157 }\end{array}$ \\
\hline \multicolumn{2}{|l|}{ JaLC DOI } \\
\hline \multicolumn{2}{|l|}{ Abstract } \\
\hline Notes & 抄録 \\
\hline Genre & Technical Report \\
\hline URL & $\begin{array}{l}\text { https://koara.lib.keio.ac.jp/xoonips/modules/xoonips/detail.php?koara_id=AN00062898-0000003 } \\
\text { 3-0157 }\end{array}$ \\
\hline
\end{tabular}

慶應義塾大学学術情報リポジトリ(KOARA)に掲載されているコンテンツの著作権は、それぞれの著作者、学会または出版社/発行者に帰属し、その権利は著作権法によって 保護されています。引用にあたっては、著作権法を遵守してご利用ください。

The copyrights of content available on the KeiO Associated Repository of Academic resources (KOARA) belong to the respective authors, academic societies, or publishers/issuers, and these rights are protected by the Japanese Copyright Act. When quoting the content, please follow the Japanese copyright act. 


\title{
Different Effects of Norepinephrine and Serotonin on the Electrical Toe Stimulation-Induced Reflexes in the Rat Spinal Cord
}

\author{
Takeshi SuzukI, Hideki ONo* and Hideomi FukUdA* \\ 鈴木岳之，小野秀樹，福田英臣
}

1. Electrical toe stimulation was shown to elicit reflex potentials in the ipsilateral common peroneal nerve in the rat.

2. This reflex consisted of the spinal reflex and the spino-bulbo-spinal reflex (SBS reflex).

3. Administration of norepinephrine into the subarachnoid space enhanced the spinal reflex but depressed the SBS reflex. On the other hand, serotonin enhanced both reflexes.

4. These different effects of norepinephrine and serotonin suggest different control of nociceptive reactions by these biogenic amines.

本報告は Gen. Pharmac., 19 (3), 373-375 (1988) に発表.

* 東京大学薬学部 